\title{
DONGENG ISLAMI UNTUK MENINGKATKAN BUDAYA LITERASI SASTRA ANAK BAGI SISWA TPQ AZ-ZUHRI
}

\author{
Evi Chamalah ${ }^{1)^{*}}$, Meilan Arsanti ${ }^{2}$, Leli Nisfi Setiana ${ }^{3}$, Turahmat ${ }^{4}$, Aida Azizah ${ }^{5}$,
} Oktarina P.W. ${ }^{6}$

1,2,3,4,5,6 Program Studi Pendidikan Bahasa dan Sastra Indonesia, Fakultas Keguruan dan

Ilmu Pendidikan Universitas Islam Sultan Agung

*chamalah@unissula.ac.id

Informasi Artikel

Terima: 07/01/2021

Revisi : 31/03/2021

Disetujui : 30/04/2021

Kata Kunci: Dongeng

Islami, Budaya

Literasi, Siswa TPG

Az-Zuhri.

\section{ABSTRAK}

Dongeng merupakan salah satu bentuk karya sastra yang memiliki banyak manfaat, salah satunya untuk meningkatkan budaya literasi. Meningkatkan budaya literasi tidak hanya untuk kegiatan membaca dan menulis, tetapi juga untuk mendengarkan dongeng. Hal itu juga dilakukan untuk siswa TPQ Az-Zuhri yang berusia 3-6 tahun. Peningkatan budaya literasi bagi siswa TPQ Az-Zuhri dilakukan dengan menyimak dan menyajikan hasil bacaan dongeng islami. Pelaksanaan kegiatan pengabdian ini menempuh lima tahap, mulai dari sosialisasi, koordinasi, penentuan waktu pelaksanaan, hingga pelaksanaan pengabdian yaitu mendengarkan dongeng islami dan mempresentasikan hasil observasi. Mahasiswa TPQ AzZuhri sangat antusias mendengarkan dongeng dan mempresentasikan hasil dari apa yang mereka dengarkan, sehingga budaya sastra dalam hal ini dongeng bisa ditingkatkan. Mendengarkan dongeng merupakan hal yang menarik dan baru bagi siswa TPQ Az-Zuhri. Kegiatan pengabdian ini baik jika ditindaklanjuti pada siswa TPQ AzZuhri usia 7-15 tahun yang memiliki kemampuan membaca dan menulis, sehingga budaya sastra dapat ditingkatkan kembali.

\section{PENDAHULUAN}

Berdasarkan hasil Test Indonesian National Assessment Programme (INAP), Tes yang mengambil sampel siswa kelas 4 di 34 provinsi menunjukkan bahwa kemampuan literasi membaca siswa masih sangat rendah. Pada literasi membaca, siswa memperoleh skor rendah pada domain kognitif C3 (menginterpretasi dan mengintegrasikan ide dan informasi), yaitu 29.65, dan C4 (mengevaluasi konten, bahasa, dan elemen-elemen teks), yaitu 22.25. Siswa tampak kurang menguasai teks sastra yang dibuktikan dengan rendahnya skor membaca teks ini (27.65) dibandingkan dengan teks nonsastra (43.34). Siswa kesulitan membaca teks panjang yang biasanya diberikan pada topik bacaan sastra dan 
teks terkait ranah C3 dan C4. Namun demikian, siswa mampu menjawab pertanyaan terkait lingkungan terdekatnya dengan baik. Siswa kesulitan menjawab pertanyaan yang menuntut penafsiran, kemampuan memparafrase teks bacaan, dan imajinasi (misalnya pertanyaan terkait perasaan tokoh cerita). Selain itu, pertanyaan mengandung istilah teknis juga sulit dipahami. Berdasarkan hal tersebut, maka pembelajaran literasi di Sekolah Dasar diperlukan untuk meningkatkan pemahaman terhadap teks bacaan sastra untuk meningkatkan kemampuan berpikir tinggi siswa (Apandi 2017). Berdasarkan pendapat Apandi tersebut, maka dapat disimpulkan bahwa literasi merupakan kemampuan yang berkaitan dengan kegiatan membaca, berpikir, dan menulis yang bertujuan untuk meningkatkan kemampuan memahami informasi secara kritis, kreatif, dan reflektif (Suyono et al 2017:17), sehingga literasi memiliki peran penting bagi kehidupan pribadi, masyarakat, juga bagi negara, maka gerakan literasi perlu diupayakan oleh semua pihak (Andina 2017, Permatasari 2015).

Menanggapi permasalahan tersebut, maka salah satu solusi yang diberikan oleh Kementerian Pendidikan dan
Kebudayaan yaitu mengembangkan Gerakan Literasi Sekolah/GLS yang berfungsi untuk mengembangkan sekolah sebagai organisasi pembelajaran. GLS adalah upaya menyeluruh yang melibatkan semua warga sekolah dan masyarakat, sebagai bagian dari ekosistem pendidikan. GLS memperkuat gerakan penumbuhan budi pekerti sebagaimana dituangkan dalam Peraturan Menteri Pendidikan dan Kebudayaan Nomor 23 Tahun 2015. Salah satu kegiatan di dalam gerakan tersebut adalah "kegiatan 15 menit membaca buku nonpelajaran sebelum waktu belajar dimulai”. Kegiatan ini dilaksanakan untuk menumbuhkan minat baca peserta didik serta meningkatkan keterampilan membaca agar pengetahuan dapat dikuasai secara lebih baik. Gerakan ini sebenarnya tidak hanya dilakukan di sekolah, namun juga bisa dilakukan di TPQ. Salah satunya adalah TPQ Az-Zuhri. Siswa di TPQ Az-Zuhri terdiri atas siswa dengan rentang usia antara 3-15 tahun. Meskipun ada beberapa siswa dalam kategori siswa SD yang notabene sudah bisa membaca dan menulis, namun kenyataannya, di TPQ Az-Zuhri siswa hanya diajarkan cara membaca AlQuran, sedangkan membaca karya sastra belum pernah dilakukan. Padahal 
menurut (Zebua 2015:87), aktivitas membaca sastra sangat penting bagi siswa, sebab di dalam teks sastra terkandung nilai-nilai yang berupa nilai estetika dan dalam isinya terkandung tema dan amanat yang sangat bermanfaat bagi setiap siswa.

Karya sastra yang dapat diajarkan pada siswa, salah satunya adalah dongeng. Dongeng merupakan salah satu media sastra yang dapat menumbuhkan minat baca (Candrika 2019). Melalui dongeng, ketertarikan terhadap buku akan muncul (Wulandari 2017:74), namun sayangnya kemampuan membaca hanya dapat dilakukan pada siswa usia sekolah dasar sampai dengan sekolah menengah. Pada umumnya, anak-anak usia dini, belum mampu mencerna cerita dalam bentuk tulisan, mereka hanya tertarik pada gambar-gambar tanpa melihat isi cerita. Pada usia tersebut, kemampuan kognitif dan psikomotorik anak sedang berkembang dengan cepat, maka banyak sekali hal-hal yang dapat dengan mudah terekam dalam ingatan anak, dan hingga dewasa kemampuan mengingatnya akan relatif terjaga (Taufik 2000). Untuk mewujudkan hal tersebut, maka diperlukan kegiatan mendengarkan dongeng. Pada kegiatan pengabdian ini diikuti oleh 20 orang siswa dengan rentang usia antara 4-6 tahun. Sebenarnya kegiatan ini bisa diikuti oleh kurang lebih sejumlah 40 siswa, namun karena pandemi covid-19 yang berkepanjangan, kegiatan pengabdian di TPQ Az-Zuhri dibatasi dengan jumlah separuhnya, agar dapat menyesuaikan protokol kesehatan. Dengan adanya kegiatan menyimak dongeng, diharapkan minat dan kemampuan membaca anak akan tumbuh sehingga kemampuan memahami bacaan akan berkembang dan anak mampu mengaitkan bacaan dengan pengalaman pribadi, berpikir kritis, dan mengolah kemampuan komunikasi secara kreatif melalui kegiatan menanggapi bacaan (Anderson \& Krathwol 2001).

Berdasarkan latar belakang tersebut, diketahui bahwa budaya literasi sastra pada siswa TPQ Az-Zuhri masih rendah. Hal ini juga dibuktikan dengan hasil wawancara dengan sejumlah siswa mengenai pengalaman mereka dalam mendengarkan dongeng islami. Maka sebenarnya diperlukan sebuah solusi untuk meningkatkan budaya literasi sastra anak yaitu dengan cara memperdengarkan dongeng islami pada siswa TPQ Az-Zuhri. Kegiatan ini bertujuan untuk meningkatkan budaya literasi sastra anak yang dilakukan dengan memperdengarkan dongeng 
islami kemudian dilakukan pendokumentasian dengan cara siswa mempresentasikan dongeng yang didengar yang berasal dari hasil pemahaman siswa setelah bersamasama mendengarkan dongeng. Pendahuluan harus berisi (secara berurutan) latar belakang umum, analisis situasi (permasalahan masyarakat, kebutuhan masyarakat), solusi, dan tujuan.

\section{METODE KEGIATAN}

Kegiatan pengabdian ini dilakukan pada siswa TPQ Az-Zuhri dengan rentang usia 3-6 tahun, yang berjumlah 20 orang siswa. Kegiatan ini dilaksanakan di TPQ Az-Zuhri yang terletak di jalan ketileng raya, kelurahan Sendangmulyo, Kecamatan Tembalang, Kota Semarang. Kegiatan pengabdian dilaksanakan selama 2 hari yaitu pada hari Jumat dan Sabtu, tanggal 27 dan 28 November 2020. Kegiatan pengabdian ini dilakukan dengan beberapa langkah yaitu sebagai berikut. Langkah pertama yaitu tim pengabdi melakukan kegiatan sosialisasi program kepada pengelola dan pengajar TPQ Az-Zuhri. Kegiatan sosialisasi bermanfaat agar pengelola dan pengajar mampu memahami manfaat mendengarkan dongeng islami bagi siswa TPQ. Langkah kedua yaitu melakukan koordinasi dengan pihak TPQ Az-Zuhri. Langkah ketiga yaitu menentukan waktu pelaksanaan program. Langkah keempat yaitu melaksanakan program berdasarkan hasil kesepakatan pihak pengurus TPQ Az-Zuhri. Langkah kelima yaitu melaksanakan program pengabdian melalui kegiatan memperdengarkan dongeng islami, kemudian siswa mempresentasikan hasil simakan. Kegiatan yang pengabdi laksanakan, telah disesuaikan dengan protokol kesehatan pada masa pandemi covid-19. Beberapa kegiatan yang seharusnya dilakukan, tidak pengabdi laksanakan, misalnya kegiatan berdiskusi dan berkelompok.

\section{HASIL DAN PEMBAHASAN}

Hasil dan pembahasan kegiatan pengabdian ini dilaksanakan dengan lima langkah seperti yang telah diuraikan pada bagian metode. Kelima langkah tersebut dapat diuraikan sebagai berikut.

\section{Kegiatan Sosialisasi Program}

Kegiatan sosialisasi sebagai langkah awal sebelum pelaksanaan kegiatan pengabdian. Dalam kegiatan sosialisasi, pengabdi dan tim menjelaskan tentang pentingnya dongeng islami sebagai bentuk peningkatan budaya literasi 
sastra bagi anak TPQ Az-Zuhri.

Kegiatan sosialisasi dilakukan secara terbatas dengan pengelola dan pengajar TPQ Az-Zuhri. Kegiatan tersebut diawali dengan pengetahuan tentang pentingnya menumbuhkan budaya literasi pada anak-anak. Budaya literasi menjadi sesuatu yang penting, apalagi pada zaman globalisasi saat ini. Banyak terjadi degradasi wawasan dan pengetahuan yang diakibatkan kurangnya budaya literasi oleh masyarakat (Hudhana dan Ariyana 2019). Selain hal tersebut, di zaman yang semakin maju, perkembangan anak belajar anak tentu akan berhubungan langsung dengan teknologi. Banyaknya fitur teknologi yang semakin canggih dapat berpengaruh negatif dan berpengaruh positif pada anak-anak. Pemanfaatan teknologi yang tepat akan menumbuhkan budaya literasi pada anak. Literasi dapat dimulai dari berbagai hal yang berhubungan dengan kecerdasan linguistik. Salah satu program yang dapat meningkatkan literasi adalah memperdengarkan dongeng islami kepada anak-anak. Selain mengandung muatan positif tentang budi pekerti yang baik, dongeng islami menjadi salah satu sarana untuk meningkatkan literasi anak melalui pemanfaatan teknologi untuk meningkatkan kecerdasan linguistik. Dengan begitu, anak dapat memperoleh manfaat positif dari mendengarkan dongeng islami.

Koordinasi dengan Pihak TPQ Az-Zuhri Kegiatan koordinasi dilakukan antara ketua tim pengabdi dengan pengelola TPQ Az-Zuhri. Hal ini dilakukan untuk mempermudah pelaksanaan kegiatan pengabdian. Kegiatan koordinasi ini diperlukan untuk menentukan beberapa aspek yang diperlukan sebelum melaksanakan pengabdian. Tim pengabdi melakukan koordinasi terkait waktu pelaksanaan program dan langkah pelaksanaan program pengabdian. Tim pengabdi juga melakukan koordinasi terkait jumlah peserta TPQ Az-Zuhri dan rentang usia peserta. Hal ini penting sebagai pertimbangan dalam pemilihan dongeng yang akan diperdengarkan kepada anakanak TPQ Az-Zuhri.

Penentuan Waktu Pelaksanaan Program Pengabdian

Penentuan waktu pelaksanaan program pengabdian dilakukan berdasarkan kesepakatan antara ketua tim pengabdi dengan pengelola TPQ yang tentunya disesuaikan dengan jam pembelajaran di TPQ Az-Zuhri. Hal ini dilakukan terkait protokol kesehatan yang harus 
diterapkan selama pandemi Covid-19. Pada bagian awal, tim pengabdi dan pihak TPQ melakukan penetapan waktu pengabdian yang dilakukan pada hari Jumat dan Sabtu, tanggal 27 dan 28 November 2020. Pengabdian dilaksanakan pada pukul 16.00 sampai 17.00 WIB. Tim peneliti dan pengelola TPQ menerapkan protokol kesehatan selama pandemi Covid-19 dengan meminta anak-anak TPQ untuk berwudhu terlebih dahulu sebelum mulai belajar, menjaga jarak antara satu anak dengan anak lainnya, memakai masker, dan meminimalisir banyaknya interaksi antara satu anak dengan anak lainnya. Hal ini dilakukan untuk mencegah penyebaran virus Covid-19.

Pelaksanaan Program Pengabdian

Kegiatan program pengabdian dilakukan melalui dua langkah, yaitu siswa diperdengarkan dongeng islami melalui media Youtube yang dapat diunduh melalui laman https://www.youtube.com/watch?v=Hq pDTwCIVs4 dan laman https://www.youtube.com/watch?v=7J1 qAI_5oHg mengenai cerita Nabi Yunus AS dan Nabi Nuh AS. Cerita ini dipilih agar anak lebih mengenal dan mencintai figure teladan yang baik (Nuryanto 2015). Hal ini juga didukung oleh Sanchez et al (2006) yang mengatakan bahwa cerita nabi dan rasul melibatkan konflik moral yang sangat berguna bagi anak-anak. Setelah anak-anak mendengarkan video tersebut, tim pengabdi menjelaskan nilai-nilai pendidikan karakter yang ada dalam cerita tersebut. Nilai karakter yang ditanamkan yaitu karakter religius. Selain itu, pengabdi juga menjelaskan bahwa cerita tersebut telah ditulis dalam Al-Quran Surat Ash-Shaafat ayat 139 yang berbunyi "Sesungguhnya Yunus Benar-Benar salah seorang rasul", QS Al-Ankabut ayat 14 yang berbunyi "Dan sesungguhnya Kami telah mengutus Nuh kepada kaumnya, maka ia tinggal di antara mereka seribu tahun kurang lima puluh tahun. Maka mereka ditimpa banjir besar, dan mereka adalah orang-orang yang zalim”, dan QS AlAnkabut ayat 15 yang berbunyi "Maka Kami selamatkan Nuh dan penumpangpenumpang bahtera itu dan Kami jadikan peristiwa itu pelajaran bagi semua umat manusia". Tim pengabdi menjelaskan makna dalam surat tersebut, agar siswa TPQ dapat lebih memahami. Berikut merupakan dokumentasi saat anak-anak diperdengarkan video dongeng islami. 


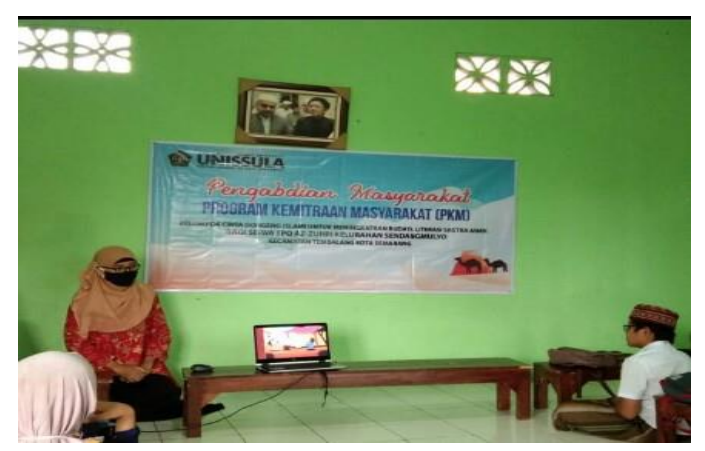

Gambar 1

Kegiatan menyimak Dongeng Islami

Setelah anak-anak diminta untuk mendengarkan dongeng islami, kemudian mereka mempresentasikan apa yang telah diperdengarkan. Anakanak sangat antusias dalam mempresentasikan apa yang telah didengar. Meskipun mereka dari usia yang beragam, yaitu antara 3-6 tahun, namun semangat mereka untuk mempresentasikan di depan kelas cukup tinggi. Mereka tidak malu-malu untuk menceritakan apa yang telah mereka dengarkan. Hal ini dapat dilihat pada dokumentasi berikut.

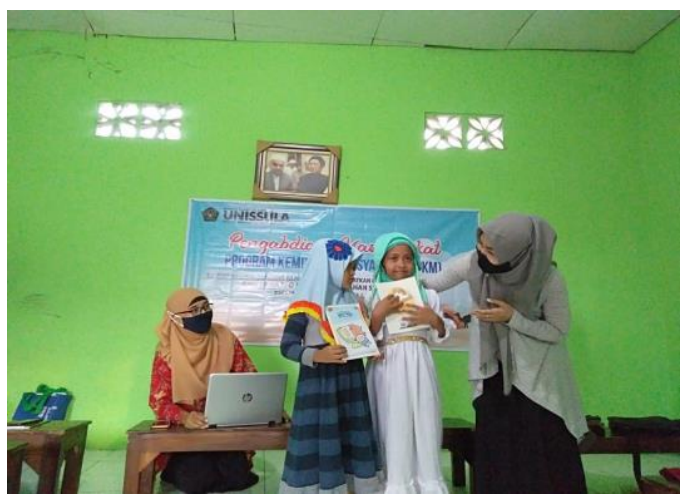

Gambar 2 Kegiatan Mempresentasikan
Peningkatan Budaya Literasi Anak melalui Dongeng Islami pada Siswa TPQ Az-Zuhri

Peningkatan budaya literasi anak pada siswa TPQ Az-Zuhti telah terlaksana dengan baik. Hal ini dapat dibuktikan dengan dokumentasi pada saat anak-anak mempresentasikan hasil simakan. Mereka mempresentasikan dengan lancar dan sangat antusias. Siswa TPQ Az-Zuhri yang semula tidak memahami tentang dongeng islami, menjadi paham dan merasa senang mendapatkan pembelajaran tersebut.

\section{PENUTUP}

Peningkatan budaya literasi anak melalui dongeng islami pada siswa TPQ Az-Zuhri telah terwujud dengan baik, melalui beberapa langkah pelaksanaan pengabdian yaitu dari mulai sosialisasi, koordinasi, penentuan waktu pelaksanaan, sampai pada pelaksanaan pengabdian, melalui mendengarkan dongeng islami dan mempresentasikan hasil simakan. Siswa TPQ Az-Zuhri sangat antusias ketika mereka mendengarkan simakan dan mempresentasikan hasil simakan. Hal tersebut merupakan hal baru bagi mereka. Oleh karena itu, alangkah baiknya jika hal ini ditindaklanjuti kembali pada siswa TPQ Az-Zuhri 
dengan rentang usia 7-15 tahun yang notabene mereka sudah bisa membaca dan menulis, sehingga budaya literasi dapat ditingkatkan kembali.

\section{DAFTAR PUSTAKA}

Anderson, Lorin W. dan David R.

Kratwohl.

(2010).

Pembelajaran, Pengajaran,

dan Asesmen. Terjemahan.

Yogyakarta: Pustaka Pelajar.

Andina, E. (2017). Pentingnya Literasi bagi Peningkatan Kualitas Pemuda. Majalah Info Singkat Kesejateraan Sosial, 9 (21), 912.

Apandi, Idris. (2017). Penguatan Gerakan Literasi pada Jenjang Sekolah Dasar. http://www.kompasiana.com/id risapandi/penguatan-gerakanliterasi-pada-jenjang-sekolahdasar_58ca7bcd4ef9fde728af59 87.

Candrika, Luh Yesi. (2019). Tantangan Budaya Literasi di Era Digitalisasi: Peranan Dongeng Lokal dalam Memperkaya Literasi Nasional. Prosiding Seminar Nasional Dharma
Acarya ke-1, Tantangan dan Peluang Dunia Pendidikan di Era 4.0, 181-190.

Hudhana, Winda Dwi dan Ariyana. (2018). Menanamkan Budaya Literasi pada Anak Usia Dini melalui Dongeng. Jurnal Lingua Rima, 7 (2), 80-85.

Nuryanto, Sidik. (2015). Internalisasi Pendidikan Karakter melalui Dongeng. Prosiding Seminar Nasional, 179-187.

Permatasari, A. (2015). Membangun Kualitas Bangsa dengan Budaya Literasi. Prosiding Seminar Nasional Bulan Bahasa UNIB, 146-156.

Suyono, et al. (2017). Implementasi Gerakan Literasi Sekolah pada Pembelajaran Tematik di Sekolah Dasar. Jurnal Sekolah Dasar. 26 (2), 116-123.

Taufik, Muhammad. (2000). Dongeng Islami: Alternatif Penanaman Nilai-Nilai kepada Anak. Majalah Ilmiah Psikologi, Kognisi, 4 (1), 26-31.

Wulandari, Ine. (2017). Peningkatan Minat Baca melalui Metode Dongeng pada Anak-Anak Aggota Sanggar Ruang Aksara Gayamharjo Kabupaten Sleman Yogyakarta. Jurnal Bakti Saintek, 1 (2), 73-77.

Zebua, Sarila. (2015). Pengembangan Bahan Ajar Membaca Sastra Indonesia dan Perangkat Penilaian Autentik. Jurnal Edukasi Kultura, 2 (2), 87-98. 